\title{
IS SOCIOLOGICAL THEORY USEFUL IN NONACADEMIC EMPLOYMENT? THE VIEWS OF SOCIOLOGISTS, EMPLOYERS, AND FORMER STUDENTS
}

\author{
Richard A. Wright \\ Kansas State University
}

Mid-American Review of Sociology, 1987, Vol. XII, No. 2:39-50

This paper summarizes and critiques previous studies of the opinions of three groups (sociologists, nonacademic employers, and former sociology students) regarding the usefulness of sociological theory in nonacademic work. Existing studies show that: (1) most sociologists agree that sociological theory has much relevance to nonacademic employment; (2) nonacademic employers are somewhat skeptical and suspicious of the relevance of theoretical skills on the job; and (3) former sociology students have ambivalent opinions regarding the usefulness of theory to their careers. The paper concludes with a brief discussion of the origins of employer suspicions concerning sociology and a call for "truth in advertising" when sociologists discuss the marketability of sociology degrees with students.

Much has been written recently about the desirability of including applied courses in undergraduate and graduate sociology curricula (see DeMartini, 1980; Rossi, 1980; Berk, 1981; Grasmick et a1., 1983; Green and Salem, 1983; Howery, 1983; Watts et al., 1983; Watts and Johnson, 1984; Freeman and Rossi, 1984; Kelly, 1986; Frey and Wright, 1987). This interest has resulted in a dramatic expansion in the number of applied courses of fered in sociology departments. For example, Howery's (1983) study of applied sociology of ferings on the undergraduate level indicates an increase in the number of departments which: (1) offer internship programs; (2) offer specific courses dealing with applied issues and nonacademic careers; and/or (3) integrate applied topics into existing courses. Similarly, DeMartini (1980) notes that while only $11 \%$ of the graduate sociology departments in the U.S. of fered applied courses in $1970,44 \%$ offered these courses by 1979 . The increased emphasis placed on applied sociology courses is largely attributable to a desire to enhance the marketability of sociology degrees for students seeking nonacademic employment (Ruggiero and Weston, 1986; Frey and Wright, 1987). 
Mid-American Review of Sociology

There is a strong consensus among sociologists writing on the topic that applied courses should stress experience-based learning and methodological, statistical, and computer skills as preparation for nonacademic careers (Caro, 1983; Watts et al., 1983; Watts and Johnson, 1984; Daudistel and Hedderson, 1984; Freeman and Rossi, 1984; Frey and Wright, 1987). Somewhat less consensus, however, exists about the usefulness of sociological theory courses for nonacademic employment. This paper summarizes the research concerning the views of three groups (sociologists, nonacademic employers, and former sociology students) regarding the importance of theoretical skills in nonacademic jobs.

\section{SOCIOLOGISTS: THE VIEW FROM THE IVORY TOWER}

While most sociologists writing on the topic contend that sociological theory courses have considerable relevance to nonacademic employment, there are a few dissenters to this view. Unfortunately, this debate has largely been waged without the benefit of empirical research as few researchers have bothered to ask sociologists about their opinions regarding the specific jobrelated skills which theory courses provide (see Howery, 1983, for an exception).

Most sociologists who consider theory of importance to nonacademic employment emphasize that theoretical models are helpful in offering alternative solutions to applied problems (Denzin, 1970; Scott and Shore, 1974; Giles-Sims and Tuchfield, 1983; Johnson, 1983). Denzin (1970:127), for example, notes that all sociological theories "contain specifications for action in the real world." As a result, approaching a practical problem with a theory "increases the probability that [effective] applied action can follow". (Denzin, 1970:127). Similarly, Giles-Sims and Tuchfield (1983) contend that "theoretically grounded" research taken from academic sociology can suggest new possibilities in the implementation of programs and policies in nonacademic work.

Other sociologists maintain that some familiarity with organizational theory is especially helpful on the job (Scott and Shore, 1974; Adamek and Boros, 1983; Haber, 1983). Adamek and Boros (1983) suggest that organizational theory can be "very useful" in helping employees understand individual behavior in an organizational context. Haber (1983) more specifically argues that insights into the internal operations of bureaucracies of fered by organizational theory are particularly crucial in the training of future program evaluators.
Theory and Nonacademic Employment

Finally, echoing the Millsian (1959) emphasis on the role of the "sociological imagination" in facilitating an understanding of the relationship between private troubles and public issues, several sociologists have stressed that theoretical skills help future nonacademic employees to become more critical and perceptive and Grabarek, 1986); Scott and Shore, 1974; Howery, 1983; Salem that theoretical in). For example, Scott and Shore (1974) contend that theoretical insight enables employees to subject the rigorous analysis and sensitizes em of proposals and programs to rigorous analysis and sensitizes employees to the complexities and theteties of social life. Salem and Grabarek (1986:274) argue that understand the help students "to develop creative abilities and to the economic system with of history and the interdependence of assume are prized by with other social institutions," talents they survey of 34 sociology departments found that sociologists repartments which of er applied courses, solving abilities" in nols theoretical skills to "critical problem theory courses are thonacademic employment. Howery notes that because theory is useful for required in applied sociology programs because theory is useful for linking practical knowledge to planned reciating to subse. She concludes that "middle range" policy theories relating to substantive specialties are essential in applied sociology
programs (Howery, 1983).

beca How's (1983) interpretations, though, are open to criticism recommendations for applied in her research design. Her on her survey of aca applied sociology programs are based solely seems reasonable that sociologists (Howery, 1983). However, it nonacademice that the consumers of applied sociology (both consulted when for yers and former students) should also be consulted when formulating an applied sociology curriculum. around eciology is by definition "client-centered" (i.e., focused around employer needs) and not thased on the theoretical concerns of the academic world (see Demerath, 1981a and 1981b). This recognition leads DeMartini (1980) to assert boldly that traditionally trained academic sociologists cannot automatically be relied on to teach applied sociology. Extending this observation to criticize Howery's study, perhaps traditionally trained academic sociologists alone cannot be expected to formulate an applied sociology curriculum that graduates marketable students.

Only a few sociologists have openly questioned the usefulness of theory in nonacademic employment. For example, while DeMartini (1980) and Giles-Sims and Tuchfield (1983) defend the importance of theory courses in applied sociology programs, they admit that applied sociology as actually practiced is largely 
atheoretical. Furthermore, in their description of the applied sociology program at the University of Oklahoma, Grasmick et al (1983:70) more bluntly contend that sociological theory "is not especially useful to [applied] students" and should be included in applied programs only to "promote departmental solidarity" and peace.

\section{NONACADEMIC EMPLOYERS: THE VIEW FROM THE OFFICE SUITE}

Employers who hire former sociology students show somewhat less enthusiasm for the use of sociological theory in applied settings. In their survey of 173 Texas nonacademic employers, Watts et al. (1983) and Watts and Johnson (1984) found that employers consider research methods and statistics as essential courses for sociology students, but rate sociological theory courses as "relatively unimportant." Even more revealing is Lyson and Squires (1982) survey of 65 nonacademic employers, all of whom employed as least one Ph.D. sociologist. Lyson and Squires (1982) found that while $89 \%$ of their respondents thought that research methods courses were important for the employment of sociology graduates and $78 \%$ thought that statistics courses were important, only $14 \%$ believed theory courses were important on the job.

Despite such findings, numerous sociologists (including Scott and Shore, 1974; Howery, 1983; Watts and Johnson, 1984; Ruggiero and Weston, 1986; Salem and Grabarek, 1986) curiously conclude that many nonacademic employers desire certain skills (e.g., critical thinking ability and creativity) that theory courses can teach. However, this conclusion appears to be an artifact of the way survey researchers phrase their questions. For example, Watts and Johnson (1984, emphasis added) asked employers: "What skills do you expect when hiring sociology" graduates?" In response, $81 \%$ of the employers said "writing ability," $70 \%$ said "taking initiative," $69 \%$ said "critical thinking," 54\% said "leadership ability," and $51 \%$ said "creativity" (Watts and Johnson, 1984). However, Watson's (1982, emphasis added) national survey of 249 employers elicited much different responses when he asked a slightly different question: "What skills do you most need when hiring sociology students?" Watson's (1982) employer respondents ranked the following skills in order of importance: (1) counseling ability; (2) writing and editing ability; (3) mathematical skills; (4) statistical skills; (5) business skills; (6) program evaluation skills; (7) personnel skills; and (8) computer skills. Comparing the Watts and Johnson (1984) and Watson (1982) studies, employers seem to be suggesting they expect sociology students to have theoretical skills (e.g., critical thinking ability and creativity) but they want sociology students with writing, quantitative, and personnel skills.

The latter interpretation is further supported by two additional findings from Watts and Johnson's (1984) study. First, only four of their 173 employer respondents reported they actually recruit sociology graduates. Second, only six employers rated sociology graduates as "attractive" employees. Graduates of 14 other college majors had higher "attractiveness" rankings than sociology graduates, including the residual category "other major" (Watts and Johnson, 1984). Employers on surveys of ten volunteered unflattering remarks indicating low toleration for sociology and critical thinking sociology students were said to have "attitude problems" and to be "liberal bleeding-hearts" and "not in touch with the reality of the business world" (Watts and Johnson, 1984:196). In a remarkable understatement, Watts and Johnson (1984:196) conclude that the "reputation of sociology students is less than outstanding in the eyes of our [nonacademic employer] respondents."

\section{FORMER SOCIOLOGY STUDENTS: THE VIEW FROM THE JOB}

Studies of former sociology students now employed in nonacademic settings reveal an ambivalence toward the usefulness of sociological theory in the working world (Lutz, 1979; Adamek and Boros, 1983; Stevens and Reynolds, 1983; Jacoby et al., 1984 Ruggiero and Weston, 1986). Two factors probably contribute to this ambivalence: (1) recent sociology graduates must compete in a tight job market holding a degree which many employers view with disdain; and (2) once employed, many former sociology students undoubtedly experience intense "antitheoretical" work socialization (exemplified by the veteran cop who advises rookies to -forget everything you learned in the police academy").

Several studies have documented the woeful state of the current job market for sociology degree holders (for reviews of this literature, see Ruggiero and Weston, 1986; Frey and Wright, 1987). For example, while research indicates that most recent sociology bachelor's alumni are employed (Hedley and Adams, 1982; Stevens and Reynolds, 1983; Ruggiero and Weston, 1986), one study showed that a majority were not employed in the types of jobs they desired and expected following graduation (Stevens and Reynolds, 1983) Furthermore, Huber (1984) estimates that between $15-20 \%$ of all recent sociology bachelor's degree graduates are underemployed, performing jobs which do not require college degrees. 
Several studies of recent sociology bachelor's alumni suggest that many wish their sociology courses had emphasized "practical" issues more and theory less (Lutz, 1979; Hedley and Adams, 1982; Stevens and Reynolds, 1983). For example, Lutz's (1979:386) survey of recent sociology graduates at the University of Northern Iowa revealed that numerous former students wish their "education had been more applied than they perceived it to have been." Likewise, Stevens and Reynolds (1983:9) survey of recent sociology graduates of Winona State University uncovered what the authors poignantly characterize as "a plea for greater career emphasis within undergraduate education." In the Stevens and Reynolds (1983) survey, respondents urged the following revisions in the sociology program: (1) greater emphasis on career counseling; (2) more extensive use of internships; (3) the introduction of applied sociology courses into the curriculum; and (4) the integration of "real world" experiences into theory courses. Other studies reveal that former students consider career counseling, management training, public speaking, and computer programming as important skills for which a sociology bachelor's degree of fers insufficient preparation (Jacoby et al., 1984; Ruggiero and Weston, 1986).

Somewhat more support for the importance of sociological theory is found among former graduate students who hold nonacademic jobs. For example, Adamek and Boros' (1983) survey of Kent State University M.A. and Ph.D. alumni working in nonacademic positions revealed that a majority felt that both methods and theory courses were "useful" on the job. While methods courses were rated "more useful" than theory courses by both M.A. and Ph.D. graduates, only $10 \%$ of the M.A. and $11 \%$ of the Ph.D. respondents rated theory courses "not usef ul" (Adamek and Boros, 1983).

\section{SUMMARY AND DISCUSSION}

Summarizing the studies reviewed in this paper, it appears that: (1) nonacademic employers are somewhat skeptical and suspicious of the skills which theory courses teach sociology students; (2) sociology alumni have ambivalent attitudes regarding the usefulness of theory in their careers; and (3) sociologists are the only ones largely convinced that theory courses have much relevance to nonacademic employment.

Because nonacademic employers are ultimately the ones who make the bread-and-butter decisions to hire, their suspicions of sociology students in general and sociological theory in particular deserve further comment. Employer suspicions are rooted in stereotypes that are legacies of the popularity of sociology as a major among college students in the late 1960s and early 1970s (Wright, 1985; Ruggiero and Weston, 1986). Numerous writers agree that employers persist in stereotyping sociology students as "liberal bleeding-hearts" and even "out and out radicals" (Smith, 1983; Sorensen, 1983; Watts and Johnson, 1984; Ruggiero and Weston, 1986).

Opinions of sociologists regarding the usefulness of theory in nonacademic employment also deserve additional comment. Sociologists currently seem to be in the proverbial position of "wanting their cake and eating it too" when it comes to making students more marketable. Many sociologists writing on applied curricula contend that students can be made more marketable without significant revisions to "core" sociology courses such as methods, theory, and substantive areas (see DeMartini, 1980; Howery, 1983; Freeman and Rossi, 1984; Jacoby et al., 1984; McMillian and McKinney, 1985). Because this "status quo" approach has failed to produce marketable students in the immediate past, however, it is wishful thinking to believe it will succeed in the near future.

Admittedly, even with dramatic applied curricular revisions, it is unlikely that sociology students will soon rival the fondness for business students in the hearts of nonacademic employers. A telling finding from Watts and Johnson's (1984:196) study demonstrates this point. When asked what sociology faculty could do to make their students more marketable, some nonacademic employers bluntly responded: "Tell students to change their major to business" (or "computer science" or "engineering").

It is perhaps time for sociologists to adopt a "truth in advertising" credo when discussing the marketability of sociology degrees with students. Sociologists should encourage students to major in sociology not because future employers will admire their critical thinking abilities and reward them with large paychecks, but because students find the subject matter intrinsically interesting. When defending the importance of sociological theory to students, honesty requires that sociologists revise the Socratic observation from Plato's "Apology" with some painful evidence from recent research: The unexamined life is not fit for human living, but it certainly pays better. 


\section{REFERENCES}

Adamek, Raymond J. and Alexander Boros

1983 "Work Experiences and Educational Evaluations of Applied Sociologists." Teaching Sociology 11 (1):8-16.

Berk, Richard A.

1981 "On the Compatibility of Applied and Basic Sociological Research: An Effort in Marriage Counseling." The American Sociologist 16 (4):204-211.

\section{Caro, Francis $\mathrm{G}$.}

1983 "Program Evaluation." Pp. 77-93 in Howard E. Freeman, Russell R. Dynes, Peter H. Rossi, and William Foote Whyte (eds.), Applied Sociology: Roles and Activities of Sociologists in Diverse Settings. San Francisco: JosseyBass.

Daudistel, Howard C. and John Hedderson

1984 "Training Evaluation Researchers: Tips on Making It Work." Teaching Sociology 11 (2):167-181.

DeMartini, Joseph $\mathrm{R}$.

1980 "Constraints in the Development of Curricula in Applied Sociology" The American Sociologist 15 (3):138-145.

\section{Demerath, N.J., III}

1981a "ASAying the Future: The Profession Versus the Discipline." The American Sociologist 16 (2):87-90.

1981b "Sacred and Profane in Sociology and Social Policy: Comparative Notes on Britain and the U.S." The American Sociologist 16 (3):136-147.

Denzin, Norman K.

1970 "Who Leads: Sociology or Society?" The American Sociologist 5 (2):125-127.

Foote, Nelson N.

1974 "Putting Sociologists to Work." The American Sociologist 9 (3):125-134.

Freeman, Howard E. and Peter H. Rossi

1984 "Furthering the Applied Side of Sociology." American Sociological Review 49 (4):571-580.

Frey, R. Scott and Richard A. Wright

1987 "Teaching Undergraduate Research Methods from an Applied Perspective." Memphis, TN: Paper presented at the Annual Meeting of the Mid-South Sociological Association, October 28-31, Memphis, Tennessee.
Giles-Sims, Jean and Barry Tuchfield

1983 "The Role of Theory in Applied Sociology." Pp. 32-50 in Howard E. Freeman, Russell R. Dynes, Peter H. Rossi, and William Foote Whyte (eds.), Applied Sociology: Roles and Activities of Sociologists in Diverse Settings. San Francisco: Jossey-Bass.

Grasmick, Harold G., Gary D. Sandefur, and Wilbur J. Scot

1983 "An M.A. Curriculum in Applied Sociology: Avoiding the Pure Versus Applied Debate." Teaching Sociology $11(1): 62-75$.

Green, Charles S., III and Richard G. Salem

1983 "The Nonsociologist as Applied Sociologist: Teaching Undergraduate Applied Sociology as Ethical Practice." Teaching Sociology 11 (1):32-46.

Haber, Lawrence D.

1983 "Government Policy Research." Pp. 128-137 in Howard E. Freeman, Russell R. Dynes, Peter H. Rossi, and William Foote Whyte (eds.), Applied Sociology: Roles and Activities of Sociologists in Diverse Settings. San Francisco: Jossey-
Bass.

Hedley, A. Alan and Susan M. Adams

1982 "The Job Market for Bachelor Degree Holders: Cumulation." The American Sociologist 17 (3):155-163.

Howery, Carla B.

1983 "Undergraduate Education." Pp. 322-347 in Howard E. Freeman, Russell R. Dynes, Peter H. Rossi, and William Foote Whyte (eds.), Applied Sociology: Roles and Activities of Sociologists in Diverse Settings. San Francisco: JosseyBass.

Huber, Bettina J.

1984 Career Possibilities for Sociology Graduates. Washingtorr, DC: American Sociological Foundation.

Jacoby, Joseph E., Meredith D. Pugh, Eldon E. Snyder, and Elmer A. Spreitzer

1984 "There is Life (and Work) After Sociology: Implications for Curriculum Design." Teaching Sociology 11 (4):399417.

Johnson, Paul L.

1983 "Human Services Planning." Pp. 106-117 in Howard E. Freeman, Russell R. Dynes, Peter H. Rossi, and William Foote Whyte (eds.), Applied Sociology: Roles and Activities of Sociologists in Diverse Settings. San Francisco: Jossey-
Bass. 
Kelly, Robert F.

1986 "Teaching Graduate Applied Sociology Through Internships: Program Development, Management, and Problems." Teaching Sociology 14 (4):234-242.

Lutz, Gene $M$.

1979 "Employment and a Liberal Arts Undergraduate Education in Sociology." Teaching Sociology 6 (4):373-390.

Lyson, Thomas A. and Gregory D. Squires

1982 "Sociologists in Nonacademic Settings: A Survey of Employers." Society for the Study of Social Problems Newsletter 13 (2):16-18.

McMillian, Martha and Kathleen McKinney

1985 "Reorganizing Sociology Undergraduate Curricula: A Case Study and Discussion of the Issues." Teaching Sociology 12 (4):425-448.

Mills, C. Wright

1959 The Sociological Imagination. New York: Oxford University Press.

\section{Rossi, Peter H.}

1980 "The Presidential Address: The Challenge and Opportunities of Applied Social Research." American Sociological Review 45 (6):889-904.

Ruggiero, Josephine A. and Louise C. Weston

1986 "Marketing the B.A. Sociologist: Implications from Research on Graduates, Employers, and Sociology Departments." Teaching Sociology 14 (4):224-233.

Salem, Richard G. and Stanislaus Grabarek

1986 "Sociology B.A.s in a Corporate Setting: How Can They Get There and What Value Are They?" Teaching Sociology 14 (4):273-275.

Scott, Robert A:-and Arnold Shore

1974 "Sociology and Policy Analysis." The American Sociologist $9(2): 51-59$.

Smith, A. Emerson

1983 "Consumer and Advertising Research." Pp. 189-199 in Howard E. Freeman, Russell R. Dynes, Peter H. Rossi, and William Foote Whyte (eds.), Applied Sociology: Roles and Activities of Sociologists in Diverse Settings. San Francisco: Jossey-Bass.
Sorenson, Robert C.

1983 "Corporate Marketing." Pp. 172-188 in Howard E. Freeman, Russell R. Dynes, Peter H. Rossi, and William Foote Whyte (eds.), Applied Sociology: Roles and Activities of Sociologists in Diverse Settings. San Francisco: JosseyBass.

Stevens, Ronald and James Reynolds

1983 "Careers and Curriculum: A Ten-Year Survey of Choices and Changes for Sociology Majors in the 1970s." American Sociological Association Teaching Newsletter 8 (1):8-10.

Watson, J. Mark

1982 "Would You Employ Sociology Majors?" Teaching Sociology 9 (2):127-135.

Watts, W. David, Alvin P. Short and Clarence C. Schultz

1983 "Applied Sociology and the Current Crisis." Teaching Sociology 11 (1):47-61.

Watts, W. David and Roland H. Johnson

1984 "Employability of Sociology Graduates, 1982." Teaching Sociology 11 (2):183-204.

Wright, Richard A. (ed.)

1985 Ideology and Controversy in the Classroom. Washington, DC: American Sociological Association Teaching Resources Center. 